\title{
ARCHITECTURAL REINTERPRETATION AND ACOUSTIC FACIES OF THE LOWER PORTION OF THE APIÚNA UNIT (CAMBRIAN DEEP-WATER DEPOSITIONAL SYSTEM, SANTA CATARINA STATE, BRAZIL)
}

\author{
GIORGIO BASÍLICI $\&$ JORGE LEONARDO MARTINS²
}

\begin{abstract}
Resumo REINTERPRETAÇÃO DA ARQUITETURA E FÁCIES ACÚSTICAS DA PORÇÃO INFERIOR DA UNIDADE APIÚNA (SISTEMA DEPOSICIONAL CAMBRIANO DE ÁGUAS PROFUNDAS, ESTADO DE SANTA CATARINA, BRASIL) Rochas sedimentares de água profunda, que afloram ao longo da BR 470, perto de Apiúna (SC), permitiram interpretar a parte inferior da unidade de Apiúna como um sistema deposicional que evoluiu de "rampa rica em areia" até "rampa de areia e pelito". Esta pesquisa contribui para o setor de exploração da indústria de petróleo com a produção: i) de um modelo conceitual de reservatórios em sistemas de água profunda tipo rampa e ii) de sismogramas sintéticos. Neste modelo são reconhecidos dois tipos de rampa. (1) Uma rampa rica de areia e caracterizada por lençóis de arenito, com aparente casualidade de construção e não ligados a canais alimentadores. Os lençóis foram gerados por fluxos bipartidos: fluxos de grãos (debris flows s.l.) na parte inferior e fluxos turbulentos (turbidity currents) na parte superior. A diferente velocidade e eficiência dos dois fluxos causaram uma desigual distribuição litológica dos lençóis: mais grossos (areia média) e espessos na parte proximal e mais finos (areia fina ou muito fina) na parte distal. (2) Uma rampa mista de areia e lama, caracterizada por um sistema de.canal - diques marginais e depósitos de intercanal. Os dois tipos de rampa representam a variação do sistema deposicional controlado provavelmente por fatores morfológico-tectônicos. Com base no modelo de arquitetura deposicional foram criados sismogramas sintéticos, usando as seções geológicas bidimensionais produzidas por dados de afloramento e interpretações deposicionais. As propriedades necessárias para construir os sismogramas sintéticos (densidades e velocidades da onda P) foram discriminadas em tabelas teóricas. Os sismogramas sintéticos permitiram definir um modelo sísmico forward e caracterizar as fácies acústicas de sistemas de rampa.
\end{abstract}

Palavras-chave: Bacia do Rio Itajaí, unidade de Apiúna, sistema deposicionais de água profunda, sistemas de rampa, modelo sísmico forward.

\begin{abstract}
An architectural model of an ancient sand-rich and mixed mud-sand ramp deep-water sedimentary environment, outcropping near Apiúna, Santa Catarina State, Brazil, is presented. This research contributes in the following way to the exploration sector of the petroleum industry: i) with a conceptual model of reservoirs in ramp deep-water systems and ii) with synthetic seismograms, based on the outcrops. Two types of ramp are recognized. One type, sand-rich, is characterized by extensive sandysheet reservoirs, not linked to proximal channels and showing an apparent casualness of construction. The mechanisms that generated the sandy-sheets were bipartite: a granular flows (debris flows s.l.), in the lower part, and a turbulent flow (turbidity currents), in the upper part. The different velocity and efficiency of the two flows produced a distinct lithological and architectural distribution of the resultant deposits: medium grain size, amalgamated and thick sandstone in the proximal part; fine - very fine grain size and thin sandstone in the distal part. (2) The second type, mixed sand-mud, is characterized by a channel-levee complex and overbank deposits. The two ramp systems represent a vertical variation of the depositional environment, controlled probably by tectonicmorphologic factors. Linked to the architectural model we produced synthetic seismograms. The properties needed for constructing the synthetic seismograms (densities and P-wave velocities) are evaluated from theoretical petrophysical tables. The synthetic seismograms allow defining a seismic forward model and characterizing the acoustic facies of ramp systems.
\end{abstract}

Keywords: Rio Itajaí basin, Apiúna unit, deep-water deposits, ramp-system, forward geoseismic model.

INTRODUCTION Deep-water depositional systems have numerous possibilities as hydrocarbon reservoirs (Weimer \& Link 1991). However, exploiting oil from these sedimentary bodies is very difficult, if conventional exploitation methods are used, and the Unrecovered Mobile Oil (UMO) can be $>70 \%$ of the Original Oil In Place (OOIP) (Tyler \& Finley 1991). One of the reasons for this is the complicated geometry of the sedimentary reservoirs.

One of the most economic and effective mean to assess the exploitation capacity of deep-water sediments is to improve the knowledge of the architecture of its depositional systems by studying analogous reservoir rocks in well exposed ancient sedimentary successions.

The main aim of this paper is to review previous interpretations of the deep-water deposits and to describe the geometrical and architectural characteristics of a deep-water ramp depositional system of the lower portion of the Apiúna unit. For this purpose, outcrop data were obtained in two different ways: i) by building a conceptual model, using the architectural analysis methods; ii) by constructing normal-incidence synthetic sections, using the $2 \mathrm{D}$ architectural model.

STUDY AREA AND GEOLOGICAL CONTEXT The Itajaí basin is located in Santa Catarina State (Southern Brazil), near Blumenau City (Fig. 1). The basin is $90 \mathrm{~km}$ long in the NE-SW direction and $20 \mathrm{~km}$ across and is covered by the Paraná Basin deposits in the SW, whereas the other margins are delimited by

1 - DGRN-Instituto de Geociências, Unicamp, CP 6152, Cidade Universitária, basilici@ige.unicamp.br, CEP13087-970, Campinas (SP) - correspondent (nuhor

2 - Observatório Nacional - MCT, R. Gal. José Cristino, 77. São Cristóvão, CEP2()921-4()(), jlmartins@on.br, Rio de Janeiro, (RJ) 
metamorphic or magmatic rocks (Fig. 1). The most recent works (Basei 1985, Rostirolla et al. 1992a, 1992b, Rostirolla \& Figueira 1995) interpret the Itajaí basin as a foreland, as an alternative to some of the previous authors (Macedo et al. 1984).

The sedimentary succession is about $4440 \mathrm{~m}$ thick. Basei (1985), Rostirolla et al. (1992a, 1992b), and Rostirolla \& Figueira (1995) recognize two main depositional sequences (Gaspar and Garcia sequences, Fig. 2), which comprise five main sedimentary phases. The Gaspar sequence is divided in two sedimentary phases, corresponding to alluvial fan-delta deposits and marine platform deposits, subjected to the influence of waves and tides. The transition to the Garcia sequence is abruptly indicated by sandstone deep-water deposits; this third sedimentary phase, which is known as Apiúna unit, is the subject of this paper. The deep-water deposits are covered by marine platform argillite deposits. The last sedimentary phase is represented by delta and fan systems.

A clear chronostratigraphic definition of the Itajaí Basin sedimentary succession does not exist. Rhiolitic hypoabyssal intrusions are dated $544 \pm 20 \mathrm{Ma}$ (Basei 1985). According to Macedo et al. (1984) and Paim et al. (1997) the basin could be attributed to the early Cambrian.

The Apiúna unit is almost $1000 \mathrm{~m}$ thick with sandstone, argillite and conglomerate siliciclastic deposits. The rocks are influenced by a very low grade of metamorphism, which does not affect the sedimentary textures and structures. The only published sedimentological data (Rostirolla \& Figueira 1995) interprets the Apiúna unit as a system of deep-water canyon-fed fan, with channel, lobe, channel-lobe transition, margin of lobe, pelite of

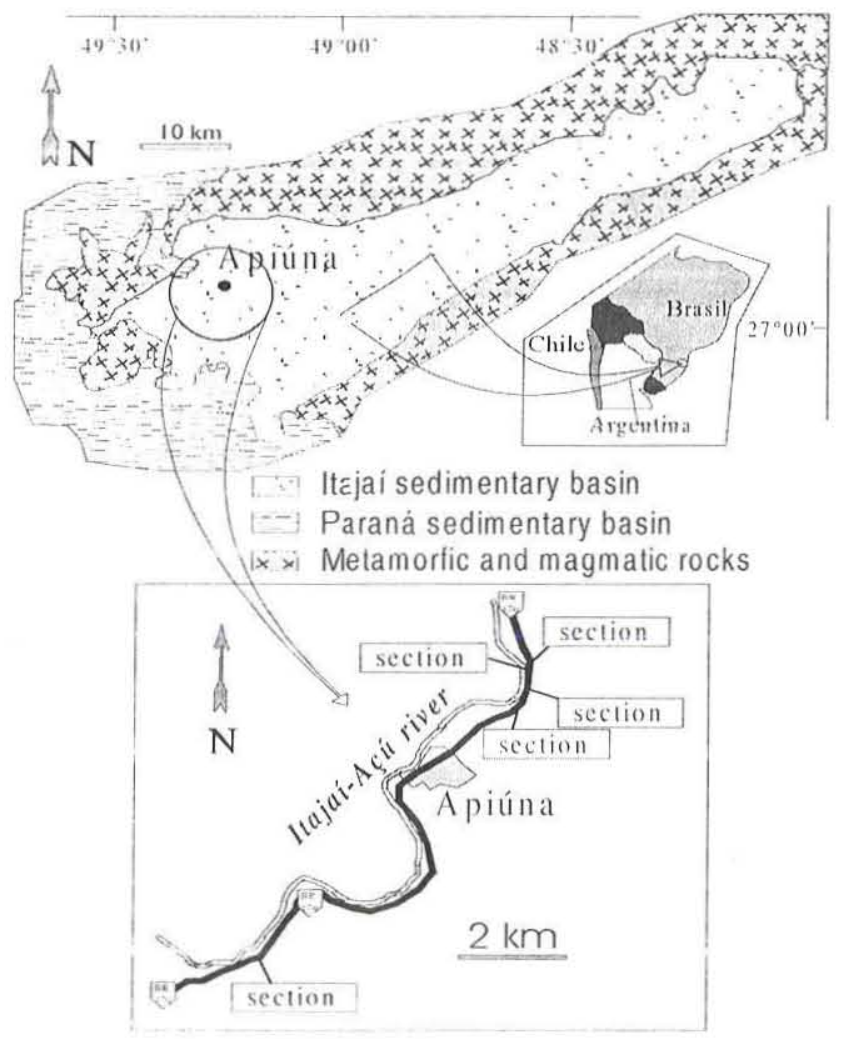

Figure 1 - Geographical and geological schematic map of the study area. In the lower picture the outcropping sections are indicated.



Figure 2 - Sketch of the sedimentary filling of the Itajai basin. The subject of this work, the Apiuna unit, is indicated. Modified from Rostirolla \& Figueira (1995).

basin plain and slumping deposits.

DEPOSITIONAL UNITS We measured and analyzed ID and 2D stratigraphic sections along the BR 470 road (Fig. I). Each bed, from $1 \mathrm{~cm}$ thick, has been analyzed with respect to its vertical and horizontal aspects, up to an observable maximum of $60 \mathrm{~m}$. Where direct analyses have been impossible, photographic sketches, up to $400 \mathrm{~m}$ wide, assisted to reconstruct the lateral depositional characteristics of the strata.

A stratigraphic interval of about $210 \mathrm{~m}$ was studied, on an estimated total thickness of the Apiúna unit of $1000 \mathrm{~m}$ (Rostirolla \& Figueira, 1995). The stratigraphic sections consist of sandstone and argillite, with minor sandy and muddy conglomerate. Due to the lack of detailed chronostratigraphic data, the correlation among sections was based on the evidence of depositional continuity and/or stratimetric and structural calculations. Four informal stratigraphical units ("depositional units" labeled A-D, from base to top) occur (Fig. 3). They have been distinguished according to lithological aspects and sequential organization of strata.

Unit A The unit A (Fig. 3) is $25 \mathrm{~m}$ thick and laterally exposed for more than $200 \mathrm{~m}$. Its base does not crop out and the top is indicated by a very sharp transition to continuous packages of sandstone strata. Almost $90 \%$ of the lithofacies consists of greenish gray argillite with thin laminae of siltstone or very fine sandstone $(<1$ $5 \mathrm{~mm}$ thick), graded, planar, parallel and laterally very continuous, in few cases characterized by very small current ripples and local contorted and folded concave depressions filled with argillite, up to $2 \mathrm{~m}$ thick and $35 \mathrm{~m}$ wide. Few lenticular rippled sandstone strata, up to $20 \mathrm{~cm}$ thick, are part of this unit.

INTERPRETATION The argillite accumulated by suspension fall-out deposition on a surface with a small gradient, as testified by the contorted argillite strata interpreted as slump deposits. The 


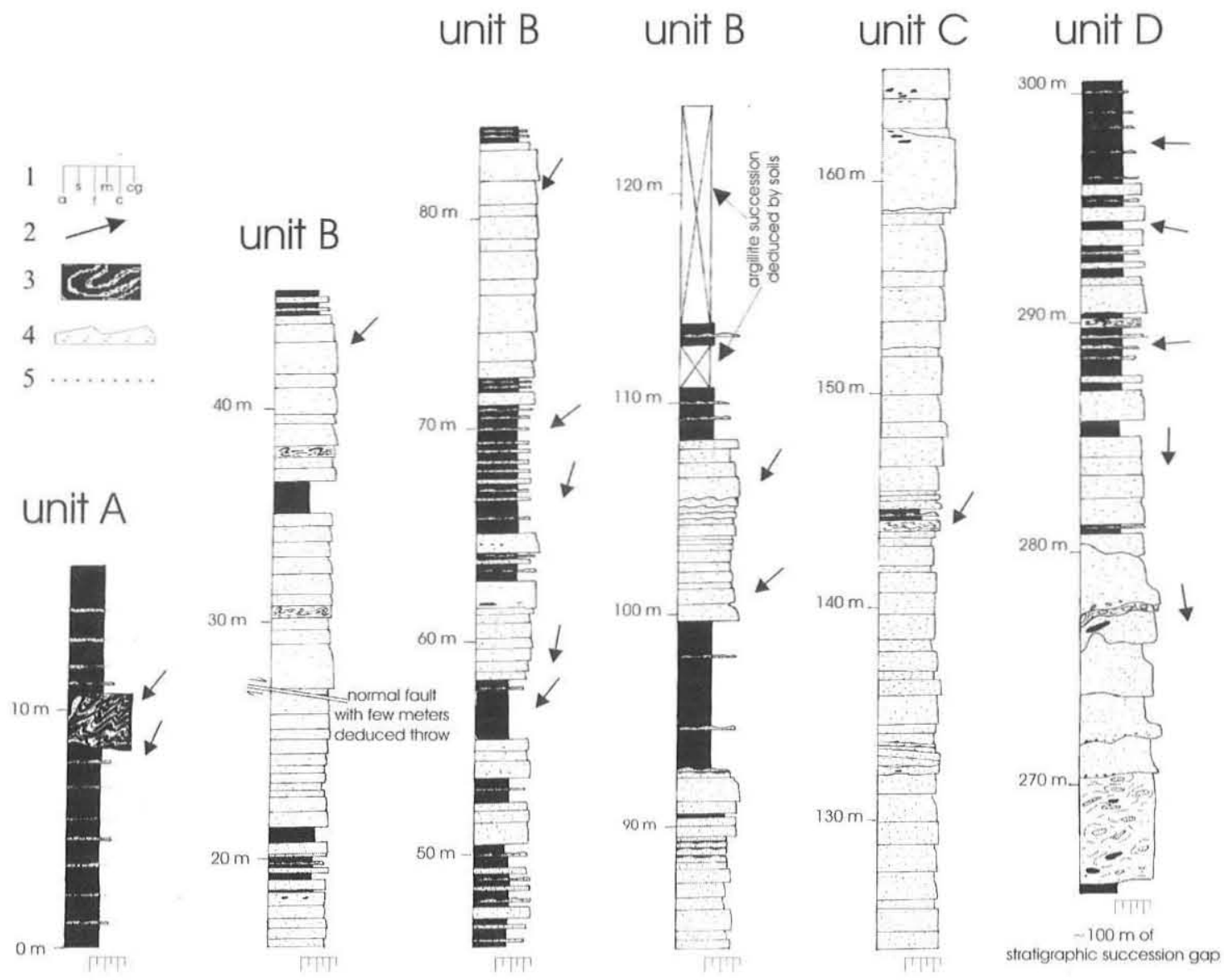

Figure 3 - Stratigraphic ID section of the succession outcropping along the BR 740 road. The depositional units are indicated at the side of the column. Graphic simplifications have been made with respect to the original stratigraphic column. The mudstone lithologies are shown in black. Note the different distribution of the sandstone strata. According to our interpretation, this succession attests a modification from a slope deposit (unit A), trough a distal sandy-rich deep-water ramp (unit B) and a proximal sandy-rich deep-water ramp (unit C) to a channel-levee system of a mixed sand-mud deep-water ramp. Legend. I: grain size, a: argillite, b: fine sandstone, m: medium sandstone, c: coarse sandstone, cg: conglomerate. 2: paleocurrent direction. 3: contorted and shumped strata. 4: top rippled strata. 5: very fine sandy laminae.

slope was tilted toward S-SW, as indicated by the ripple foresets of the sandstone and the axis of slumping deposits. Sandstone strata and laminae were deposited by low-concentration turbidity currents, hut these depositional mechanisms were very unusual and they did not build regular sandstone depositional structures; the area was probably starving or bypassed by the sandy input. The predominance of fine-grained deposits, the unstable conditions of the depositional surface, the starvation and/or bypassing of coarse sedimentary input, and the absence of sequential organization of the strata have been interpreted as slope deposits by Pickering (1983).

Units B and C Unit B overlies unit A (Fig. 3) and it represents the first significant input of sandy deposits. Unit B is about $110 \mathrm{~m}$ thick, with maximum lateral exposure of each stratum of $400 \mathrm{~m}$. The unit is dominated by three main lithofacies: a) sandstone strata packages, b) fine- to very fine sandstone strata alternated with sandy argillite siltstone, c) argillite, d) chaotic strata. More than $60 \%$ in volume consists of packages of fine or medium sandstone strata (Fig. 4) with 3 to $100 \mathrm{~cm}$ thick, ungraded and with sharp decrease of grain size only in the last upper few centimeters.

Their bottom is planar, while the top commonly shows undulated bed forms, corresponding to current ripples. Mud clasts, up to I $\mathrm{m}$ long $a$ axis, are frequently dispersed within the sandstone. Laminae of grain dimensional segregation, attributable to traction carpet (Lowe 1982, Mutti 1992, Sohn 1997), also occur. The 2D view of the strata is rectangular, at least for $200 \mathrm{~m}$. Lense-shaped strata are very rare. Nearly $20 \%$ of the lithofacies is represented by fine- to very fine sandstone alternated with sandy argillite siltstone (Fig. 5). The sandstone strata (1-28 $\mathrm{cm}$ thick) are frequently characterized by planar parallel laminations, overlain by current ripple laminations.

The sandy argillite siltstone strata are massive. Four greenish gray argillite intervals break the sandstone succession (Fig. 3) and, as the argillite of unit A, they are massive or show siltstone or very fine sandstone laminae and very fine rippled sandstone strata, up to $5 \mathrm{~cm}$ thick. The thickness of the argillite intervals varies from $1.5 \mathrm{~m}$ to $15 \mathrm{~m}$. Unit B is also characterized by chaotic strata, $15 \mathrm{~cm}$ thick, interpreted as original sandstone-siltstone-argillite alternations destroyed during sliding events. 


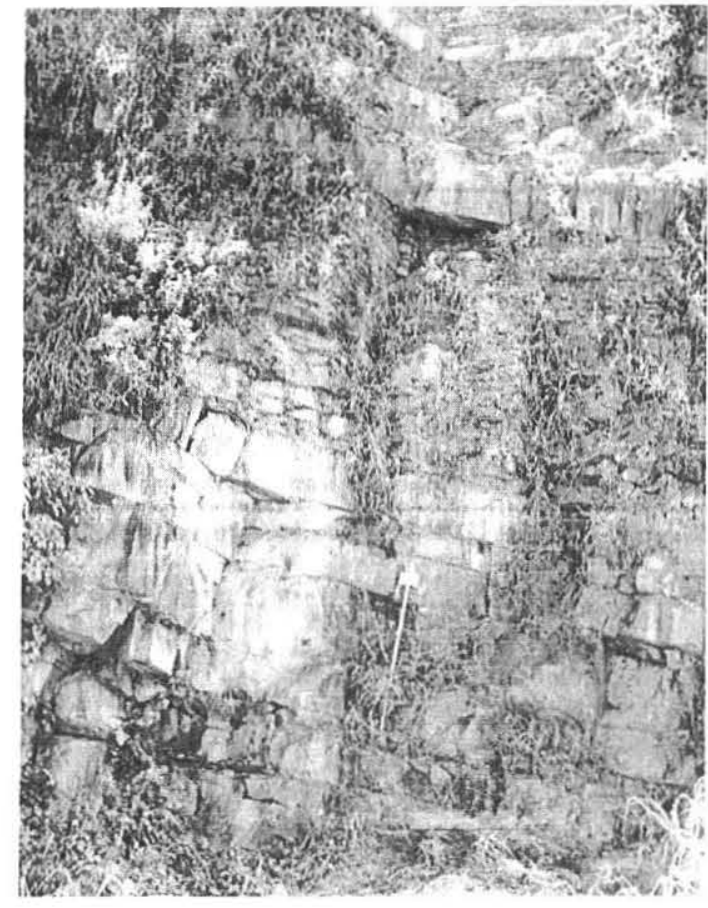

Figure 4 - A depositional sequence of fine medium-grained sandstone beds, from a few centimeters to one meter thick, is shown near the Jacob's stick. The sequence is formed by sheet sandstone deposited in a distal part of a deep-water ramp system from bipartite gravity flows. The base of the Jacob's stick is at stratigraphic position $40 \mathrm{~m}$ in unit B. The thinly stratified succession abore this sequence corresponds with fine - very fine sandstome strata alternated with sandy argillite siltstone.

Unit C is $41 \mathrm{~m}$ thick and can be latarelly followed up to $60 \mathrm{~m}$. This unit consists of sandstone strata without finer interstrata. The lower contact with the unit B is covered, but small outcrops and morphological and structural aspects suggest that the contact is stratigraphic and characterized by a sharp transition to sandy sedimentation (Fig. 3). The dominant facies ( $70 \%$ in volume) is made up of massive amalgamated strata of medium and coarse to medium sandstone, rectangular in shape, up to $1.8 \mathrm{~m}$ thick, more than $50 \mathrm{~m}$ wide perpendicular to the paleocurrent direction (Fig. 6). The bottom of the strata is planar and smooth, frequently with floating mud clasts in the medium or lower part of the bed. Planar laminae, similar to traction carpet, are rare and occur in the lower part of the bed, and rare cross laminations cover the bed. The upper part of unit $\mathrm{C}$ contains massive conglomerate sandstone ( $16 \%$ in volume) with local scoured bottom.

This unit also contains chaotic strata produced by sliding of recently deposited sediments and thin sandstone strata alternated with sandy argillite siltstone, that constitute $8 \%$ of the volume.

INTERPRETATION The medium and coarse sandstone strata of units $\mathrm{B}$ and $\mathrm{C}$ have the following analogous features: rectangular shape, linear and smooth bottom, massivity, floating mud clasts, top covered by current ripple bed forms. On the other hand: the sandy bodies of the unit $C$ are thicker (up to $1.8 \mathrm{~m}$ ), coarser (medium or medium - coarse sandstone), and not alternated with argillite siltstone.

Massive sandstone strata mean lack of turbulence during the



Figure 5 - Thin sandstone strata characterized by planar parallel and cross laminations, alternated with sandy argillite siltstone. They were formed from true turbidity currents in the distal part of a deep-water sandy ramp.

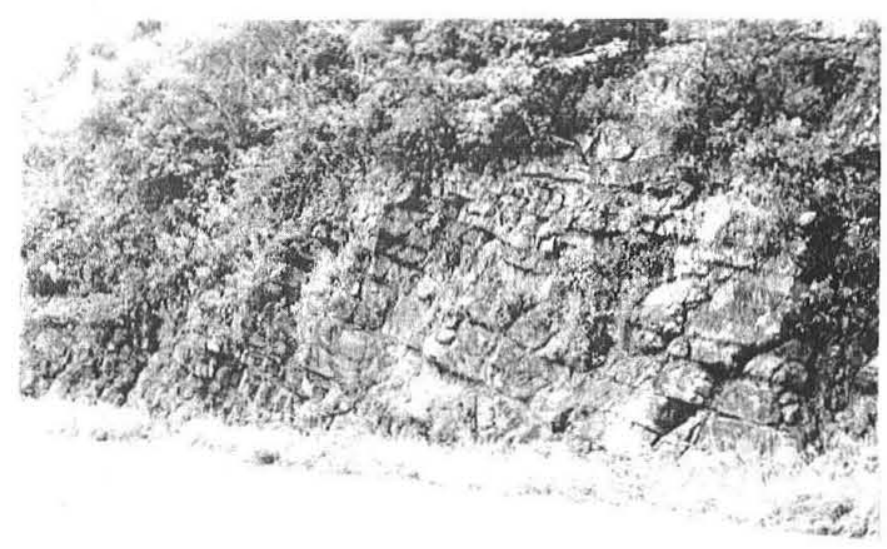

Figure 6 - Massive amalgamated coarse medium-grained sandstone constitute the proximal part of a deep-water sandrich ramp. They were deposited by high-density non-turbulent flows. Each continuous depositional sequence is up to $19 \mathrm{~m}$ thick.

last depositional processes and, therefore deposition from nonturbulent currents. Floating mud clasts, up to $1 \mathrm{~m}$ long, indicate that other forces, such as buoyancy, dispersive pressure, attrition and matrix strength, sustained the grain. These are typical of highdensity flows, such as debris flows s.l. (Lowe 1982, Mulder \& Alexander 20(01). The bottom of sandstone strata lacks erosive sole marks (like flute, gutter, groove, obstacle scour), which are normally produced by turbulent currents. Traction carpets are produced by laminar flows, and are absent in turbulent flows (Shanmugam \& Moiola 1995, Shanmugam 1997). Thus, the massive sandstone are characteristic of high-density non-turbulent flows deposits. Notwithstanding, the upper part of the sandstone strata, mainly in the unit B, shows cross laminations produced by turbulent flows, such as turbidity currents. In this way, we propose that a sandstone bed was formed for the most part by high-density nonturbulent flows and, only the upper part (the ripple bed forms and the overlying fine interval), was deposited by turbidity currents. Based on the ideas of Sanders (1965), Postma et al. (1988) and Mutti et al. (1999), we suggest, as original mechanism for the 
formation of massive sandy bodies, a bipartite density-stratified flow. Our deposition model concerns with a transport mechanism divided in two parts (Fig. 7): a lower part with laminar and pseudoplastic flow (high-density non-turbulent flow) and an upper part with turbulent flow (turbidity current). Sedimentary processes caused a thick ungraded sandy stratum from the high-density non-turbulent flow, whereas the turbidity current deposited few centimeters of fine sand and sandy argillite siltstone at the top of the previous deposit.

In the current direction, as the power and competence of the flow decreased, the deposits show: i) a decrease in the grain size and in the amount of sand transported by high-density nonturbulent flow, and ii) a contemporary increase in the depositional influence of the turbidity current, which is faster and more efficient. Therefore, in the more proximal part of the depositional area coarser, thicker, massive sandy strata with rare rippled top (unit C) occur, whereas in the distal part thinner, finer sandy strata with rippled top (unit B) occur (Fig. 7). Following this depositional hypothesis the unit $\mathrm{C}$ and $\mathrm{B}$ should represent the proximal and the distal part of the same depositional system, respectively. In this context we may interpret the rippled thin beds of fine sandstone, alternated with argillite siltstone, as produced by the more distal part of the above described bipartite depositional processes. In fact, the upper turbulent flow continues to carry fine sand and silty clay after the deposition of the high-density non-turbulent flow. More distally, these turbulent flows deposited thin rippled sandy strata covered by argillite siltstone (Fig. 7).

The depositional mechanism, described above, produced sheet sandstone strata $>50 \mathrm{~m}$ wide, up to $1.8 \mathrm{~m}$ thick, with undetermined length. The succession of several depositional events created superposed sandy bodies, 3 to $19 \mathrm{~m}$ thick, fining and thinning toward the paleocurrent direction.

The morphological conditions of the depositional area of units $B$ and $C$ should not be very different from that of unit $A$, as testified by the sliding deposits, which record a slightly inclined depositional surface.
The four argillite intervals in unit B, interlayered with the sandstone packages, represent an interruption of the coarse sedimentation. Two of these are thin (up to $2.6 \mathrm{~m}$ ), and show lenticular shape; they could mean a local interruption of sandy deposits, because of the lateral shift of the sedimentary entry point. The other two are thicker (up to $15 \mathrm{~m}$ ) and laterally continuous for more than $100 \mathrm{~m}$; they represent an interruption in the sandy input. Apparently, in the unit C coarser input interruption is not recorded.

Unit D The unit D crops out $8 \mathrm{~km} \mathrm{SW}$ of unit C. According to stratimetric calculations, unit $\mathrm{D}$ remains about $100 \mathrm{~m}$ above unit $\mathrm{C}$; between unit $C$ and unit $D$ there are no significant outcrops.

The unit D (Fig. 3) is $35 \mathrm{~m}$ thick and can be divided in a lower portion, $19 \mathrm{~m}$ thick, made up of coarser deposits, and an upper portion, $16 \mathrm{~m}$ thick, made up of finer deposits. The lower portion covers with erosive surface argillite strata, and, just at bottom, there is a muddy conglomerate, whose clasts range from pebble to boulders. Conglomeratic sandstone and medium to very coarse sandstone form lenticular bodies, $1.5 \mathrm{~m}$ to $2.5 \mathrm{~m}$ thick; erosive surfaces divide the bottom and the top of the strata and give a lenticular shape to the beds, which are about $60 \mathrm{~m}$ wide, perpendicularly to the paleocurrents.

Sole casts record paleocurrents toward S-SW. In the higher part of the lower portion, lenticular sandstone strata are replaced from rectangular bodies, with a flat top, and rare erosive bottom. In the upper portion unit D changes radically the facies association: lenticular rippled sandstone strata, $2-22 \mathrm{~cm}$ thick, with flat bottom and undulated top alternate with silty-sandy argillite (Fig. 8).

Commonly, the sandstone strata show current ripples directed toward W, which are at high angle with respect to the recorded paleocurrents in the lower portion. The sandstone strata vary laterally in thickness and pinch out terminations are commonly observed at $30 \mathrm{~m}$ of distance. The percentage distribution of the sandstone varies from $80 \%$ to $<30 \%$, showing an upward decrease. Rectangular sandstone beds, up to $135 \mathrm{~cm}$ thick, are interlayered
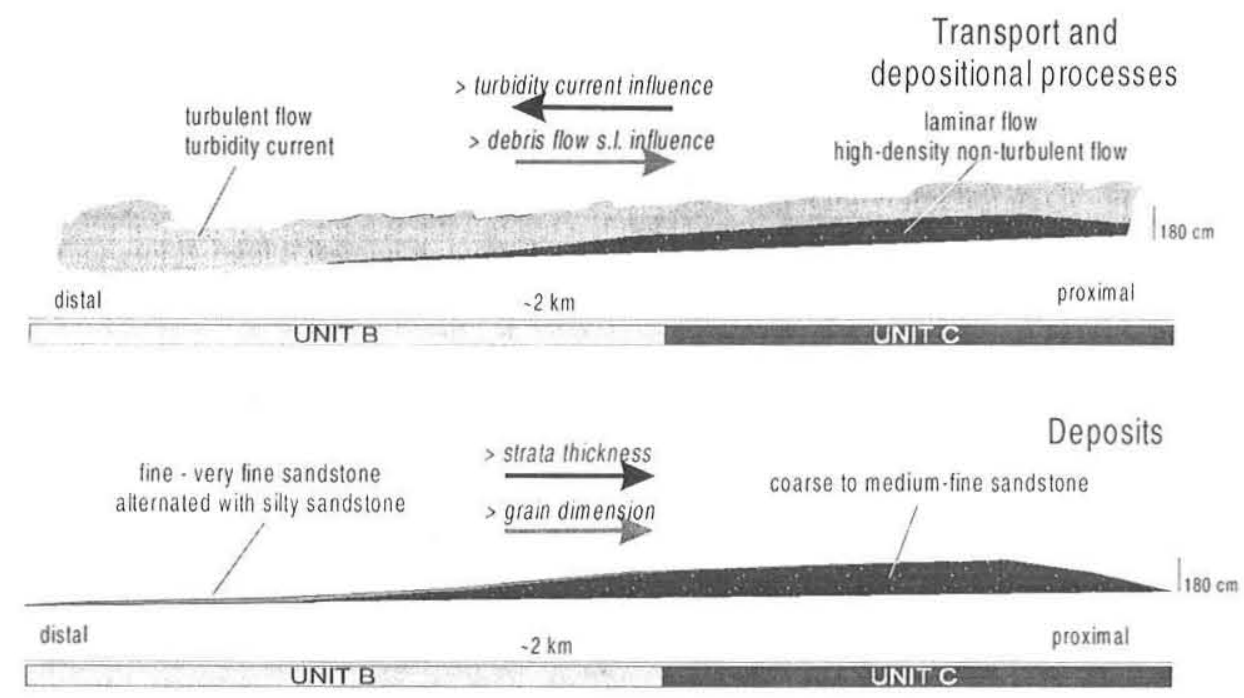

Figure 7 - Transport and depositional model for most of the sandstone bodies of the units $B$ and $C$. The model consists in a bipartite density-stratified flow, constituted by a high-density non-turbulent flow (debris flow s.l.) in the lower part and by a true turbidity current in the upper part. The sedimentary influence of the debris flow s.l. is greater. The turbidity current deposit is limited to thin layers above the debris flow s.l. or thin strata in proximal part of the flow. A minimum $2 \mathrm{~km}$ long depositional model is based on outcrop data. 
in the upper portion with the facies described above. These strata are laterally continuous for more than $50 \mathrm{~m}$, massive, locally characterized by erosive depressions and show the thickness decreases upward. Chaotic strata formed by local sliding may also occur.

INTERPRETATION The contact of the lower portion of the unit D lies on argillite by means of an erosion surface. Highconcentration mass flows are responsible for the sedimentation of the lenticular coarse deposits. Cohesive debris flows deposited muddy conglomerate and grain flows s.l. produced the conglomerate sandstone. The geometry of the bodies and the interpreted sedimentary processes allow deducing that the highconcentration mass flows were driven and deposited in a confined and erosive depression, i.e. a channel. The upward decrease in grain size and thickness of the beds testify, during the progressive filling, a local decreasing in competence and transport capacity in the channel. The facies association of the upper portion records decrease in sandy input, decrease in the energy of the depositional flows and paleocurrents perpendicular to the channel flow direction. The depositional mechanisms of the lenticular sandy strata could be attributed to true turbidity currents. As the facies association of the upper portion overlies in continuity the channel deposits and as the sandstone strata show perpendicular paleocurrents, we interpret these as overbank or levee deposits. The upper portion shows similarity with the succession described in the Echo Group (Mutti 1977) of the Pyrenees as deposits of channel margins. In this context, the thin lenticular sandstone strata are interpreted as moderate turbidity currents, which went out of the channel. When more powerful flows overbanked, they deposited thicker sandy strata with locally erosive bottom.

Two other aspects allow us to make hypotheses on the architectural features of unit D: a) we note an upward decreasing in the thickness of the sandstone strata, b) channel paleocurrents are directed toward S-SW and overlying levee facies have paleocurrents directed toward the $\mathrm{W}$. This indicate that the channel underwent, contemporary to the local filling, a lateral migration toward E. Actually, $500 \mathrm{~m}$ E of unit D and at higher stratigraphic position, a sandy conglomerate crops out, testifying to the lateral migration of the channel.

THE CONCEPTUAL MODEL We created a 2D model, where geometrical and lithological data are real or deduced from the depositional mechanism interpretation. The detail used in this $2 \mathrm{D}$ model is a compromise between the need to characterize the different depositional units and the possibility of acoustic resolution at different frequencies; in this way the generated model is a "simplification" of the sedimentological data. Below we present a sedimentary model and a lithological architecture and afterwards we will discuss the spatial and temporal evolution of the depositional units.

The unit $\mathrm{A}$ indicates that the depositional area was gently inclined and devoid of sand deposition due to insufficient sandy input and/or bypassing of sandy driving flows (Fig. 9). The high abundance of fine deposits (more than 95\%), the recording of depositional surface instability (slumping deposits), the insufficiency and/or bypassing of coarser clastic input and the lack of sedimentary sequential organization are elements already recognized in ancient or actual slope deposits (Mutti \& Ricci Lucchi 1972. Pickering 1983, Galloway 1998). The sedimentary structures indicate a S-SW dipping slope.

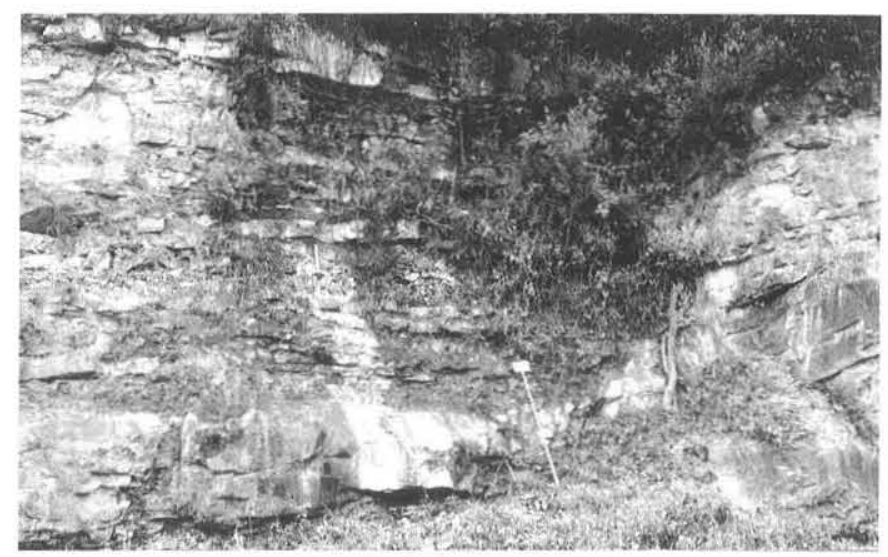

Figure 8 - Fine-grained sandstone strata alternated with siltysandy argillite, which make up the upper part of unit $D$ (stratigraphic quote $288 \mathrm{~m}$ ) and cover the conglomeratic sandstone. The transition is gradual in a typical fining and thinning upward depositional sequence. Thicker sandstone strata, about $1 \mathrm{~m}$ thick (near the Jacob's stick), alternate with thin lenticular rippled sandstone. Paleocurrent at high angle with respect to the underlying filled channel, help to interpret this succession as a levee (or overbank) depositional area.

The transition to unit B is marked by a sudden input of sand. With the start of unit B the area became a site of sandy deposition, although the general morphological conditions did not vary; in fact, sliding deposits and paleocurrent directions of the gravity flow still indicate a S-SW dipping slope. The unit B and C are dominated by extensive sheet sandstone. We associated the two units with the same depositional system, considering unit $\mathrm{C}$ as proximal and unit B as distal. In the proximal part, the sheet sandstone is coarser and thicker, lacking finer interlayering and, in many cases, the beds are amalgamated. In the distal part, the sandy strata are finer and thinner, and pelitic interlayering is very common. In the proximal part (unit C), a planar concave sandstone body with erosive base and structures of lateral accretion on the upper part, could be attributed to a small sinuous channel. However, this structure constitutes a small part $(5 \%)$ of the whole unit C; thus, the presence of channelized structures in unit $\mathrm{C}$ are irrelevant.

Grain size and thickness vertical variations of the strata do not show a clear organization; particularly coarsening and thickening upward sedimentary sequences are not observed in units B or C. For these reasons we did not interpret these bodies as lobes s.s. which are described as produced by turbidity current deposits and showing a vertical sedimentary sequence (Mutti \& Ricci Lucchi 1972, Ricci Lucchi 1975, Pickering 1983). We presume that the lack of organization of the sandstone strata could be due to: a) different origin of sandy input, and b) arrhythmic variations in the sandy input and/or energy of the sediment mechanisms.

Analogous non-organized vertical succession of deep-water sandstone bodies have been described by Surlyk (1987), who interprets these sandstone strata as deposited on a distal part of a slope surface from multiple entry points. The sedimentary succession of units B and C is also very similar to those described by Heller \& Dickinson (1985). The Apiúna unit sedimentary succession has strong analogies with the Tyee Formation and Matilija Formation (Heller \& Dickinson 1985), such as: i) the sandy deposits are dominantly massive and show similar 


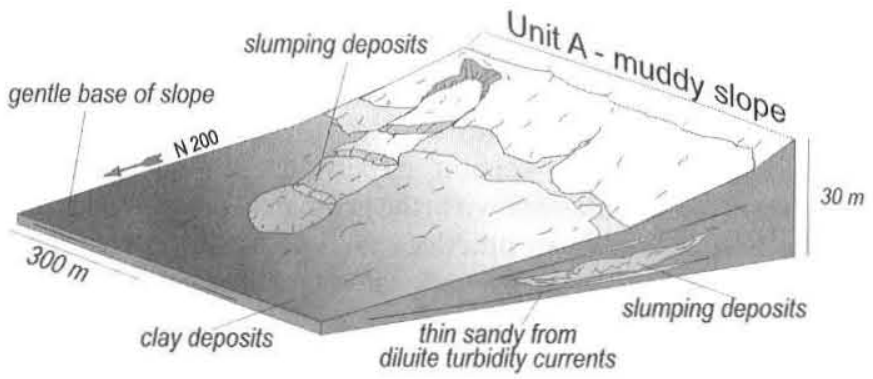

Figure 9. Depositional model of unit A. This unit corresponds to a muddy slope. Sandy input was absent or it bypassed; slumping deposits indicate gently inclined depositional surface.

sedimentological characteristics, ii) the vertical distribution of the sandstone thickness appears to be random, for example no clear asymmetric cycles of thickening or thinning sequences are found, iii) no evidence for facies segregation into channel or interchannel deposits is found, iv) the fine deposits of unit A do not represent a muddy basin, but a muddy slope. Heller \& Dickinson (1985) described the Tyee Formation and Matilija Formation as different from the classical canyon-fed fan and named this depositional system a ramp. Reading \& Richards (1994), Richards (1996) and Richards et al. (1998) suggested twelve different depositional models for deep-water systems, based on the grain size and the source of the clastic input. According to these models, units B and $C$ could be interpreted as sand-rich and multiple source input, and identified as sand-rich ramp depositional systems (Fig. 10).

Unit D is interpreted as a channel-levee complex (Fig. 11). The channel filling thickness is $19 \mathrm{~m}$, it is filled with conglomerate sandstone, but in the lower part muddy conglomerate occurs; facies analysis suggests that the channel migrated eastward at the same time as the channel filling, producing a oblique channel body. Upwardly the coarse channel filling passes to overbank or levee deposits, made up of lenticular sandstone strata alternated with silty sandy argillite.

The deposition of unit D occurred in the same general



Figure 10 - Sketch that shows the depositional model of the unit $C$ and D. Sandstone sheet strata are the main architectural elements. They deposited at the base of the slope from multiple sediment sources and built a sandy platform, named ramp. Each sandy sheet shows a downcurrent decrease in grain-size and strata thickness, as a consequence of downcurrent variation in the transport mechanisms: from prevalent high-density nonturbulent flow in the proximal part toward prevalent turbidity current in the distal part.

morphological conditions as the other units, as testified by the channel paleocurrents (S-SW) and the frequent microslumping. However we believe that unit $\mathrm{D}$ represents a radical change in the depositional system. Particularly we think that unit D is not a lateral expression of the sand-rich ramp (units B and C). Indeed, the sand-rich ramp model is characterized by the absence of channel distributors (Richards et al. 1998). Thus, we think that the presence of a well-developed channel system means an increase in clay in the clastic input that transformed a sand-rich ramp into a mixed sand-mud ramp (unit D). According to Richards et al. (1998), the mixed sand-mud system is constituted by proximal channel-levee complexes, similar to unit D, and by distal lobes. Only the channellevee deposits crop out in the Apiúna unit.

The entire measured succession records the rapid evolution of a deep-water depositional environment. The bottom of the succession (unit $\mathrm{A}$ ) represents a gently inclined slope. The transition to unit B is very rapid; it points out the beginning of the

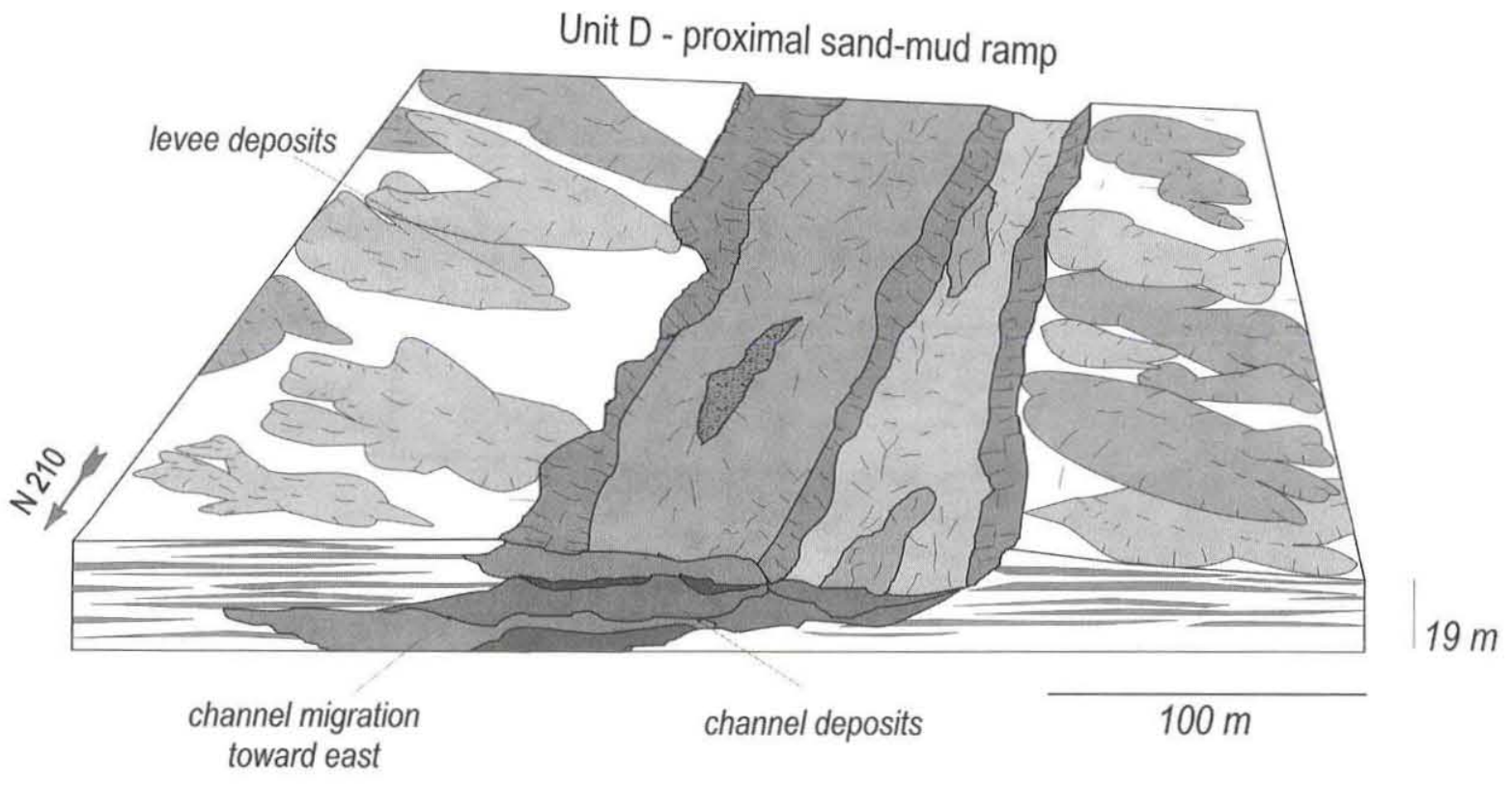

Figure 11 - Unit D is interpreted as the channel-levee succession. The channel filling is fining and thinning upward, passing from channel to overbank or levee conditions. Sedimentological considerations allow interpreting progressive eastward channel migration. 
sandy deposition in an area with very similar morphological aspects to the slope. For this reason, we think that the transition from unit A (slope) to unit B (ramp) represents a progradation of a sandy depositional system (delta?) located toward the land (Fig. 12). In fact, we do not have information about the presence of erosive channels in unit $\mathrm{A}$, constituting route passing of coarser sediments toward the lowest part of the basin. Units B and C constitute a ramp system and their evolution is interpreted as a progradation of the ramp. Four main silty argillite strata, constituting interruptions of the sandy input, occur. The two thinnest strata have a limited lateral continuity, so they could represent only a local interruption of the sandy input, for example, due to shifting of the source point. The other two strata are thicker ( 7 and $15 \mathrm{~m}$ ) and could represent general interruption of the coarser input.

The change from sand-rich ramp (units B and C) to mixed sandmud ramp (unit D) is related to an increase in the muddy input. The mud increase triggered the complete reorganization of the depositional system and consequently of the architecture in a mixed sand-mud ramp. Nelson \& Maldonado (1988), Richards \& Bowman (1998) and Richards et al. (1998) described similar systems as characterized by channel-levee complexes in the proximal part and by sandy sheet (named lobes, in the cited works) in the distal part.

The sedimentary history of the Itajaí basin is very diversified, mainly controlled by tectonic changes(Basei 1985). Morphological variations in the basin, as well as in the sediment source areas, could be responsible for the change of the slope, through a sandrich ramp, dominated by sheet sand strata, to a mixed sand-mud ramp, dominated by proximal channel-levee complex and distal lobes (Fig. 12). Eustatic variations could be superimposed and could have partially controlled this architecture. They could be responsible for minor dimension architectural elements, such as the silty argillite intervals in unit $\mathrm{B}$.

THESEISMIC ASPECTSOFTHEMODEIS We applied forward modeling to the conceptual geological model (Fig. 13).

By using forward modeling, we aimed at investigating the possible seismic expressions of the geological architecture shown by the outcropping data. It was obvious, however, that the structures appearing in the model were too thin to be identified within the conventional seismic bandwidth (over $10^{2} \mathrm{~Hz}$ ). Therefore, only a high-resolution seismic experiment would favor the delineation of the bodies shown in the geological model. Although generally unavailable in practice, such data can be routinely acquired to help constructing architectural models. Consequently, the generated models could be correlated with other interpreted from outcrop data. Examples of high-resolution reflection seismics can be found in Lericolais et al. (1990) and Lazaratos et al. (1993).

High-resolution reflection data were simulated by applying the convolutional process. In its simplest form, convolution applied to seismics requires a wavelet and a series of normal-incidence reflection coefficients (reflectivity) as input data. Convolution of both quantities generates a synthetic seismic trace. We defined each seismic trace at equidistant points $(5 \mathrm{~m})$ along the top of each geological section. At each location, an acoustic impedance profile was established by specifying densities to each body present in the sections. From a commonly used empirical relationship (Schön 1996), the acoustic velocities of each body were calculated. These data are shown in Table 1. Outcrop data interpretation of the Apiúna unit led us to identify the seismic facies as shown in Fig. 13. Together with such classification, selected studies from the petrophysical literature (Schön 1996) were used as criteria to define the densities in Table 1 .

The key parameters to generate high-resolution seismic data are the sampling rate (or sampling time interval) and the prevailing frequency of the input wavelet. Three synthetic seismic sections with distinct frequency content were generated. All resulting sections are shown in Figs. 14 and 15; seismic traces were sampled at $250 \mu \mathrm{s}$. The frequency content for each seismic section was determined by the prevailing frequency of the Ricker wavelet, which was used to perform convolution with the reflectivity along the specified locations of the corresponding geological model. Wavelets with dominant frequencies of $250 \mathrm{~Hz}, 500 \mathrm{~Hz}$ and 1000 $\mathrm{Hz}$ (2I samples) provided the synthetic sections exhibited in Figs. 14 and 15. The impulsive response, which is the response of the earth to a unity impulse, was also determined in this work for the

$40 \mathrm{~km}(?)$

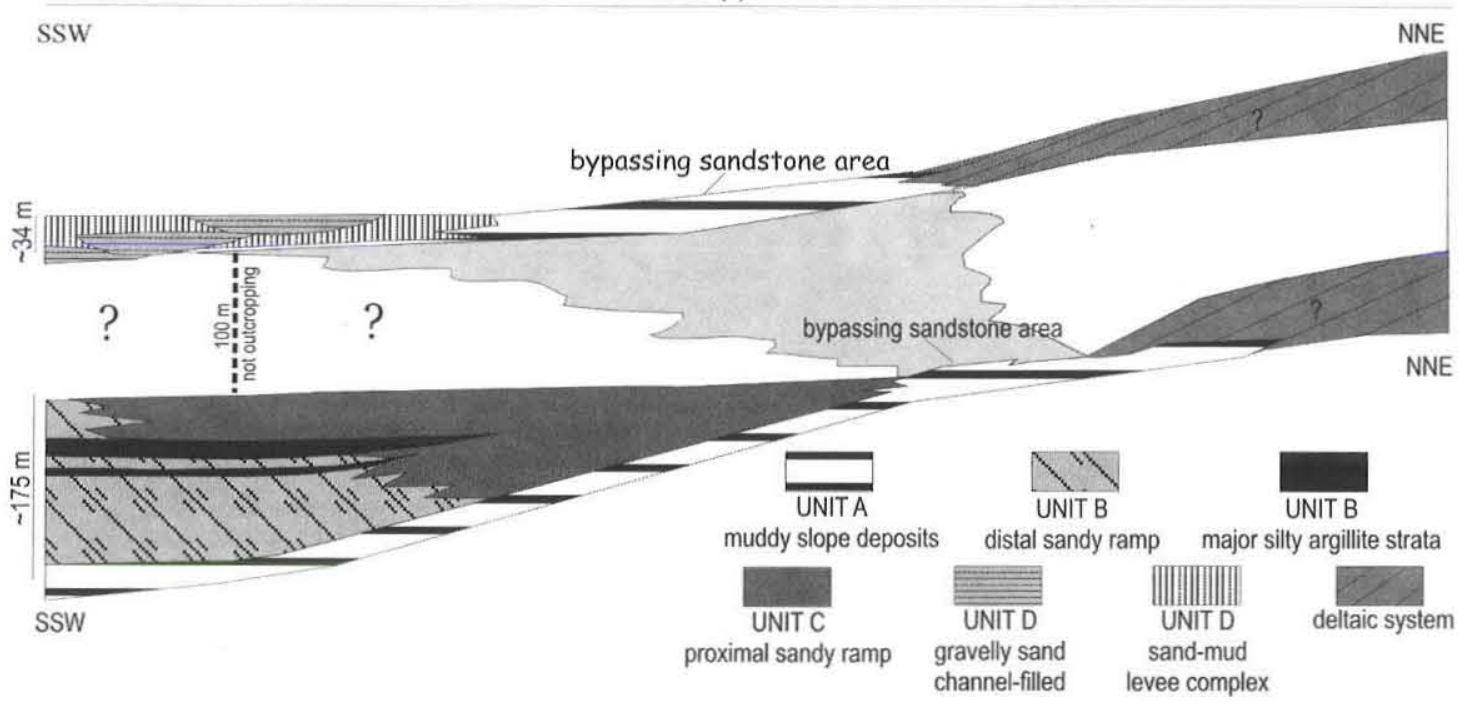

Figure 12 - Tivo-dimensional conceptual reconstruction of the studied part of the Apiuna unit. The proximal delta system is inferred. The succession shown in Figure 3 corresponds to the left part of the picture. The $40 \mathrm{~km}$ basin length is assumed from mapping data. 
Seismic facies classification

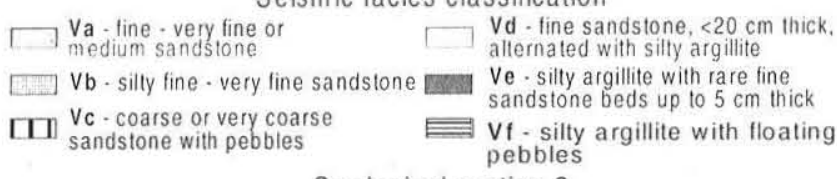

Geological section 2

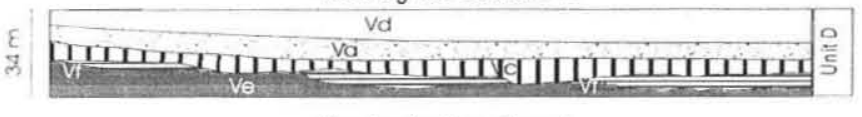

Geological section 1

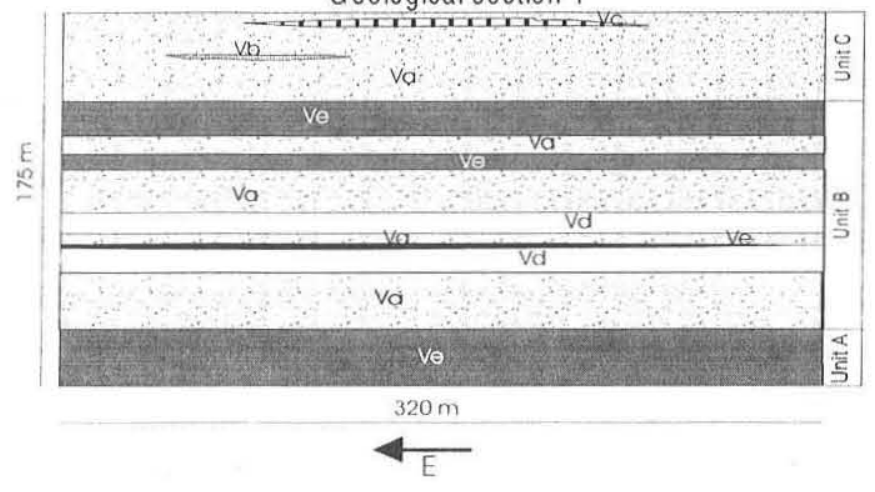

Figure 13 - Interpreted 2D conceptual stratigraphical architecture of the Apiuna unit. The body geometry is based on outcrop data and on facies analysis interpretation. We transformed the facies associations of the depositional unit (right column) in seismic facies using the lithological features of the sediments.

model (Fig. 14). We used such sections in order to facilitate the analysis of the outcome in terms of vertical resolution. In the seismic context, vertical resolution refers to the minimum separation between top and bottom of a layer or a stack of layers. This minimum separation is directly related to the dominant frequency in the seismic section. The classical study of Widess (1973) defines $\lambda / 4$ as the limit of resolution in a seismic section. Such widely accepted criterion constrains the vertical resolution by the dominant wavelength $(\lambda)$ of the seismic signal (the wavelet). At this limit (i.e.. $\lambda 4$ ), an amplitude anomaly appears in the seismic trace (tuning) caused by constructive interference of the vertical bounds (top and bottom) of the layer. The top and bottom of a layer are no longer identified in seismic traces beyond the tuning point, making seismic interpretation very difficult.

These aspects of vertical resolution were observed in the constructed synthetic seismic sections. An input wavelet with prevailing frequency of $1000 \mathrm{~Hz}$, at least, would be necessary to resolve the bodies forming the architectural model proposed. This is confirmed when comparing the right sections in figure 15 with the impulsive response in figure 14 . The seismic sections produced with a $250-\mathrm{Hz}$ input wavelet (right sections in Fig. 14) show tuning effects everywhere, causing the disappearance, for instance, of the small lens of section 2 (Fig. 13) just below $20 \mathrm{~ms}$. In figure 15 , we observe that a $500-\mathrm{Hz}$ input wavelet would hardly satisfy the resolution requirements for the architectural model proposed.

DISCUSSION As the deep-water depositional systems make up one of the most important hydrocarbon reservoirs of the world (Shanmugam \& Moiola 1988, Stow \& Johansson 2000), this work contributes to the petroleum geology.
The main reservoir in a sand-rich ramp is an extensive architectural element, named sheet sandstone. In our conceptual model, the sand-rich ramp shows thick and coarse sandstone strata, forming in the proximal part (unit C) continuous sedimentary sequences up to $40 \mathrm{~m}$ thick and more than $300 \mathrm{~m}$ wide. In the distal part (unit B) the sheet sandstone are finer and thinner, comprising continuous sequences up to $11 \mathrm{~m}$ thick and more than $300 \mathrm{~m}$ wide, frequently interlayered with finer sealing rocks (silty argillite). Consequently, in the sand-rich ramp the best reservoirs are located in the proximal part of the system. As the sand-rich system does not possess developed channel deposits, when applying this model to an oil field, it is useless to search for channel deposit reservoirs towards the proximal part of the system.

Reservoir rocks in mixed sand-mud ramp have other shape, size and distribution. In our outcrop model we examined only the channel and the overbank-levee deposits. The channel is a conglomerate sandstone or coarse sandstone body, $19 \mathrm{~m}$ thick, more than $50 \mathrm{~m}$ wide, with concave erosive bottom and flat top; it was affected by lateral migration, which produced a low angle inclined body of amalgamated channel fills. Channel reservoirs are completely surrounded by finer levee or overbank deposits, which make up sealing rocks. The shape of the channel reservoir is more irregular and the size smaller than the sheet sandstone reservoir in sand-rich ramps. Moreover, channel deposits are characterized by strong inner variations in porosity and permeability, as muddy conglomerate, deposited by cohesive debris flow, interlayering with coarse permeable deposits.

The acoustic facies characterizing the slope architectural element (unit A) is relatively homogeneous, the upper boundary is planar, parallel and continuous. The distal sand ramp element (unit B) is distinguished for having many high- and moderateamplitude reflections, all of which show planar parallel continuous surfaces. The acoustic facies of sandy proximal ramp (unit C) is more homogeneous with respect to the distal ramp, being featured by few low-amplitude surface reflectors, corresponding to low channel filling; the boundary surface with the distal ramp is planar and parallel. The sand-mud rich ramp of this model shows only the channel element (unit D); the channel bottom has a very marked, irregular and oblique high-amplitude reflections; the upper boundary is a moderate-amplitude reflection oblique and more continuous; low-amplitude reflection within the channel-fill separate bodies of different petrophysical characteristics; the upper part, characterized by overbank or levee elements, shows low- or moderate-amplitude reflections indicating lithological variations.

Table 1 - Density and acoustic velocities for the lithological facies shown in Fig. 13. To define densities values we used petrophysical values from the literature (Schön 1996). A commonly used empirical formula (Gardner et al. 1974) helped to estimate seismic $P$-wave velocities.

\begin{tabular}{ccc}
\hline FACIES & $\begin{array}{c}\text { DENSITIES } \\
{\left[\mathrm{g} / \mathrm{cm}^{3}\right]}\end{array}$ & $\begin{array}{c}\text { VELOCITIES } \\
\mathrm{Vp}=108 \mathrm{~d}^{4}[\mathrm{~m} / \mathrm{s}]\end{array}$ \\
\hline $\mathrm{Va}$ & 2.25 & 2768 \\
$\mathrm{Vb}$ & 2.20 & 2530 \\
$\mathrm{Vc}$ & 2.15 & 2308 \\
$\mathrm{Vd}$ & 2.30 & 3023 \\
$\mathrm{Ve}$ & 2.40 & 3583 \\
$\mathrm{Vf}$ & 2.35 & 3294 \\
\hline
\end{tabular}



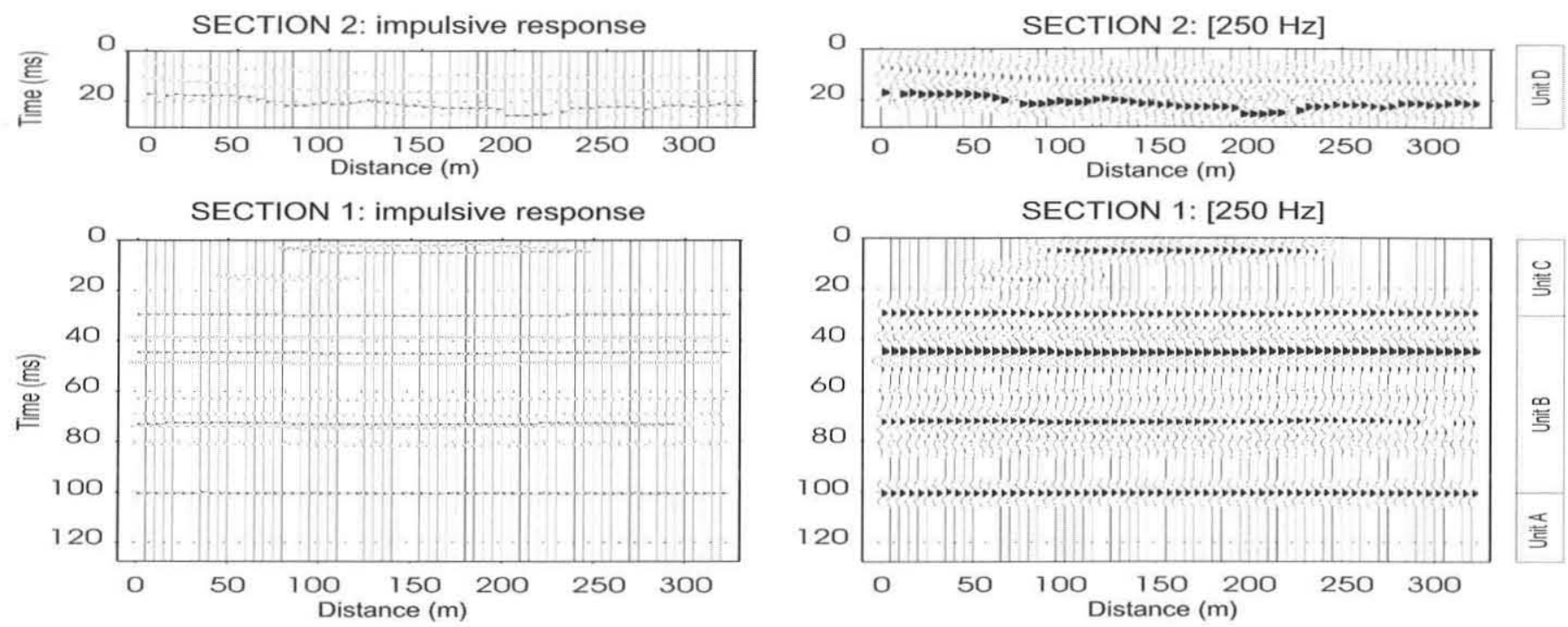

Figure 14 - Impulsive responses and corresponding synthetic seismic sections for each conceptual geological model in Fig. 13. A wavelet with dominant frequency of $250 \mathrm{~Hz}$ was used in the application of forward seismic modeling to the architectural model in Fig. 13. See text for comments.


Figure 15 - Synthetic seismic section of wavelet with dominant frequencies of $500 \mathrm{~Hz}$ and $1000 \mathrm{~Hz}$, generated by applying forward seismic modeling to the architectural model in Fig. 13. See text for comments.

For identification of the main geological features in seismic sections, high frequencies are necessary. Nevertheless, the use of high frequencies is uncommon in the industry, when, in the context of conventional seismic exploration, field frequencies are nearly 1()$^{2} \mathrm{~Hz}$. By using special seismic methods, like crosswell imaging (Lazaratos et al. 1993) in which frequencies are nearly $1000 \mathrm{~Hz}$, we believe that it is possible to observe several characterizing features of the architectural elements that describe the depositional system studied in Figs. 14 and 15.

SUMMARY AND CONCLUSIONS From outcropping deepwater clastic deposits we have: i) constructed an architectural model and ii) produced synthetic seismic sections from a 2D geological model.

The main conclusions are as follows:

(1) The lower succession of the Apiúna unit is interpreted as a deep-water depositional environment fed from multiple source points (ramp). This interpretation differs substantially from the previous works that explained these deposits as classical submarine fan, with channels, lobes and associated deposits. Our interpretation emphasizes the diversity of deep-water deposits and the corresponding style of the sedimentary architecture.

(2) The analyzed succession of the Apiúna unit records a dynamic evolution of a gently inclined lower part of a slope. The sedimentary succession passes from a muddy slope, with absent or scarce sandy input (unit A), through a sand-rich ramp system, represented 
by distal (unit B) and proximal part (unit C), to a mixed sand-mud ramp, represented by a channel-levee complex (unit D). As the Itajaí basin seems to have subjected to a very strong tectonic influence in its evolution, we also inferred that tectonically induced morphological variations on the basin and on the source area controlled the depositional system modifications.

(3) Reservoir organization varies according to the architectural model. In sand-rich ramp the best reservoirs are located in the proximal part, where sandy sheet amalgamated strata form sequences up to $40 \mathrm{~m}$ thick; in the distal part the sandstone sequences are $15 \mathrm{~m}$ thick and frequently alternated with thin pelitic deposits, and do not constitute attractive reservoirs. In the mixed sandy-mud ramp only the channel-levee complex crops out. The channel forms a reservoir $19 \mathrm{~m}$ thick, and more than $50 \mathrm{~m}$ wide; muddy debris flows, interlayered with the sandstone strata, make this reservoirs less interesting than the sheet sandstone.

(4) A characterization of acoustic facies of the studied depositional system was achieved by using forward seismic modeling. Frequencies higher than $250 \mathrm{~Hz}$ allowed defining different acoustic facies that identify the main architectural elements described in outcrops. Although high frequencies are uncommon in the context of conventional seismic exploration, the outcomes obtained modeling clearly showed the need for implementation of a very high-resolution field survey in order to construct a more refined geological model for reservoir simulation.

Acknowledgements To FAPESP (proc. no. 98/ 04461-0), ANP (PRH-ANP/MME/MCT no. 15, under proc. no. 48610.0(02779/9931 ) and Cepetro/Unicamp for financial suport. To the RBG reviewers for comments on the first draft.

\section{References}

Basei M.A.S. 1985. O cinturão Dom Feliciano em Santa Catarina. São Paulo, Tese de Doutoramento, Instituto de Geociências, Universidade de São Paulo, 193 p.

Galloway W.E. 1998. Siliciclastic slope and base-of-slope depositional systems: component facies, stratigraphic architecture, and classification. Am. Assoc. Petrol. Geol. Bull., 82(4): 569-595

Gardner, G. H. F., Gardner, L. W., Gregory, A. R. 1974. Formation velocity and density: The diagnostic basis for stratigraphic trap. Geophysics, 39: 770-780.

Heller, P.H. \& Dickinson W.R. 1985. Submarine Ramp Facies Model for Delta-Fed, Sand-Rich Turbidite Systems. Am. Assoc. Petrol. Geol. Bull.. 69(6):960-976

Lazaratos S.K., Rector III J.W., Harris J.M., Van Schaack M. 1993. High-resolution crosswell reflection imaging: potential and technical difficulties, Geophysics, 58:1270-1280

Lericolais G.. Allenou J.-P., Berne S., Morgan P. 1990. A new system for acquisition and processing of very high-resolution seismic reflection data. Geophysics, 55: 1036-1046

Lowe D.R. 1982. Sediment gravity flows: II. Depositional models with special reference to the deposits of high-density turbidity currents. J. Sedim. Petrol., 52:279-297

Macedo M.H.F., Basei M.A.S., Bonhome M.G., Kawashita K. 1984. Dados geocronológicos referentes às Rochas Metasedimentares do Grupo Itajaí (SC). Rev. Bras. Geociências, 14(1):30-34

Mulder. T. \& Alexander, J. 2001. The Physical Character of Subaqueous Sedimentary Density Flows and their Deposits. Sedimentology, 48(2):269-299

Mutti E. 1977. Distinctive thin-bedded turbidite facies and related depositional environments in the Eocene Hecho Group (South-Central Pyrenees, Spain). Sedimentology, 24:107-131

Mutti E. 1992. Tiurbidite sandstone. Agip Spa, Milano, 276 pp.

Mulli E. \& Ricci Lucchi F. 1972. Le torbiditi dell Appennino settentrionale: introduzione all' analisi di facies. Memorie della Societc̀ Geologica Italicana, 11:161-199

Mutti E., Tinterri R., Remacha E., Mavilla N., Angella S., Fava L. 1999 (Eds.). An introduction to the Analysis of Ancient Turbidite Basins from an Outcrop Perspective. AAPG (Continuing Education Course
Note Series, 39), $61 \mathrm{pp}$.

Nelson C.H. \& Maldonado, A. 1988. Factors Controlling Depositional Patterns of Ebro Turbidite Systems, Mediterranean Sea. Am. Assoc: Petrol. Geol. Bull., 72 (6):698-716

Paim P.S.G., Leipnitz I., Da Rosa A.L.Z., Da Rosa A.A.S. 1997. Preliminary report on the occurrence of Chancelloria sp. in the Itajai basin, Southern Brazil. Rev. Bras. Geoc.,27(3):303-308

Pickering K.T. 1983. Transitional submarine fan deposits from the late Precambrian Kongsfjord formations submarine fan, NE Finnmark, N. Norway. Sedimentology, 30:181-199

Postma G., Nemec W., Kleinspehn K. 1988. Large floating clasts in turbidites: a mechanism for their emplacement. Sediment. Geol., $58: 47-61$

Reading H.G. \& Richards M.T. 1994. Turbidite systems in deep water basin margins classified by grain-size and feeder system. Am. Assoc. Petrol. Geol. Bull., 78:792-822

Ricci Lucchi F. 1975. Depositional cycles in two turbidite formations of northern Apennines. J. Sed. Petrol., 45:1-43

Richards M. \& Bowman, M. 1998. Submarine-fan and related depositional systems II: variability in reservoir architecture and wireline log character: Marine and Petroleum Geology, 15:821-839

Richards M.T., Bowman M., Reading H.G. 1998. Submarine-fan systems I: characterization and stratigraphic prediction. Marine and Petroleum Geology, 15:689-717

Richards, M.T. 1996. Deep-marine clastic systems. In: Emery D. \& Myers K.J. (eds.), Sequence stratigraphy, Blackwell Science, pp.: $178-210$

Rostirolla S.P., Alkmim F.F., Soares P.C. 1992(a). O Grupo Itajaí, SC, Brasil: exemplo de sedimentação em uma bacia flexural de antepaís. Boletim de Geociências da Petrobras, 6: 109-122

Rostirolla S.P., Alkmim F.F., Soares P.C. 1992(b). Análise estrutural da tectônica deformadora da bacia de Itajaí, estado de Santa Catarina, Brasil. Boletim de Geociências da Petrobras, 6:123-147

Rostirolla S.P. \& Figueira E.G. 1995. Associações de facies turbidíticas do Grupo Itajaí, SC: sedimentação de água profunda em uma bacia de antepaís. Bol. Par: de Geociências, 43:79-944

Sanders J.E. 1965. Primary sedimentary structures formed by turbidity 
currents and related resedimentation mechanisms. $\ln$ G.V. Middleton (eds.): Primary sedimentary structures and their hydrodynamic interpretations, Soc. Econ. Paleont. Mineral. (Spec. Publ. 12), pp.: 192-219

Schön J. H. 1996. Physical properties of rocks: findamentals and principles of petrophysics, Handbook of Geophysical Exploration, 18, Pergamon Press, $583 \mathrm{pp}$.

Shanmugam G. 1997. The Bouma sequence and the turbidite mind set. Earth Science Reviews, 42:201-229

Shanmugam G. 2000. 50 years of the turbidite paradigm (1950s_.1990s): deep-water processes and facies models - a critical perspective. Marine and Petroleum Geology, 17:285-342

Shanmugam G. \& Moiola R.J. 1988. Submarine fans: characteristics, models, classifications, and reservoir potential. Earth Science Review, 24:383-428

Shanmugam G. \& Moiola, R.J. 1995. Reinterpretation of depositional processing in a clastic flysch sequence (Pennsylvanian Jackfork Group), Ouachita Mountains, Arkansas and Oklahoma. Am. Assoc. Petrol. Geol. Bull., 79:672-695

Sohn, Y.K. 1997. On traction-carpet sedimentation. J. Sedimentary Reseurch. 67:502-509

Stow D.A.V. \& Johansson M. 2000. Deep-water massive sands: nature, origin and hydrocarbon implications. Marine and Petroleum Geology, 17:145-174

Surlyk F. 1987. Slope and deep shelf gully sandstone, upper Jurassic. east Greenland. Am. Assoc. Petrol. Geol. Bull.. 71:464-475

Tyler N. \& Finley R.J. 1991. Architectural control on the recovery of hydrocarbon from sandstone reservoirs, $I n$ : Miall A.D. \& Tyler N. (eds.) The three dimensional facies architecture of terrigenous clastic sediments and its implications for hydrocarbon discovery and recovery. SEPM (Concepts in Sedimentology and Paleontology, 3). pp.: $1-5$

Weimer P. \& Link M.H. (eds.) 1991. Seismic Facies and Sedimentary Processes of Submarine Fans and Turbidite System.s. Berlin Heidelberg, Springer-Verlag, 447 pp.

Widess M. 1973. How thin is a thin bed? Geophysics, 36:1176-1180

Manuscrito A-1378

Recebido em 27 de setembro de 2002

Revisão dos autores em 14 de abril de 2004

Revisão aceita em 16 de maio de 2004 